\title{
Author Correction: Increasing the bactofection capacity of a mammalian expression vector by removal of the f1 ori
}

\author{
Síle A. Johnson ${ }^{1} \cdot$ Michael J. Ormsby $\mathbb{1}^{1} \cdot$ Anne Mclntosh ${ }^{1} \cdot$ Stephen W. G. Tait $\mathbb{D}^{2} \cdot$ Karen Blyth $^{2} \cdot$ Daniel M. Wall ${ }^{1}$
}

Published online: 20 February 2019

(c) The Author(s) 2019. This article is published with open access

\section{Correction to: Cancer Gene Therapy (2018); https://doi.org/10.1038/s41417-018-0039-9; published on 13 August 2018.}

This article was originally published under Nature Research's License to Publish, but has now been made available under a [CC BY 4.0] license. The PDF and HTML versions of the article have been modified accordingly.
Open Access This article is licensed under a Creative Commons Attribution 4.0 International License, which permits use, sharing, adaptation, distribution and reproduction in any medium or format, as long as you give appropriate credit to the original author(s) and the source, provide a link to the Creative Commons license, and indicate if changes were made. The images or other third party material in this article are included in the article's Creative Commons license, unless indicated otherwise in a credit line to the material. If material is not included in the article's Creative Commons license and your intended use is not permitted by statutory regulation or exceeds the permitted use, you will need to obtain permission directly from the copyright holder. To view a copy of this license, visit http://creativecommons. org/licenses/by/4.0/.
These authors contributed equally: Síle A. Johnson, Michael J. Ormsby.

The original article can be found online at https://doi.org/10.1038/ s41417-018-0039-9.

Daniel M. Wall

Donal.Wall@glasgow.ac.uk

1 Institute of Infection, Immunity and Inflammation, College of Medical, Veterinary and Life Sciences, Sir Graeme Davies Building, University of Glasgow, Glasgow G12 8TA, UK

2 Cancer Research UK Beatson Institute, University of Glasgow, Garscube Estate, Switchback Road, Glasgow G61 1BD, UK 